\title{
Self-Referencing and Political Candidate Brands: A Congruency Perspective
}

\section{Authors: Francisco Guzmán, Audhesh K. Paswan \& Eric Van Steenburg}

This is an Accepted Manuscript of an article published in Journal of Political Marketing on January 2015, available online: http://www.tandfonline.com/10.1080/15377857.2014.990837.

Francisco Guzmán, Audhesh K. Paswan \& Eric Van Steenburg (2015) Self-Referencing and Political Candidate Brands: A Congruency Perspective, Journal of Political Marketing, 14:1-2, 175-199, DOI: 10.1080/15377857.2014.990837

Made available through Montana State University's ScholarWorks scholarworks. montana.edu 


\title{
Self-Referencing and Political Candidate Brands: A Congruency Perspective
}

\author{
FRANCISCO GUZMÁN and AUDHESH K. PASWAN \\ University of North Texas, Denton, Texas, USA \\ ERIC VAN STEENBURG \\ James Madison University in Harrisonburg, Virginia, USA
}

\begin{abstract}
Although political and marketing analysts commonly describe political candidates as brands, the conceptualization of political candidates as brands within academic research and popular culture is uncommon. This paper presents empirical evidence in support of viewing candidates as such. Using data from a nationwide study that measures the self concept of Mexican voters and their perceived images of the presidential candidates in Mexico's 2006 election, the paper demonstrates that voters see themselves and each candidate as a distinct brand. Furthermore, this view of a voter's self-brand influences his or her perception of a political candidate's brand image. The academic and managerial implications of these findings are discussed.
\end{abstract}

KEYWORDS brand image, self-referencing, political candidates, political brands

During the last two decades, the cost of elections has escalated throughout the world. The total cost of the 2008 United States election has been estimated by the Center for Responsive Politics at $\$ 5.3$ billion, $\$ 2.4$ billion for the presidential race alone. The Electoral Commission - an independent party funding watchdog in the United Kingdom-has estimated a total expenditure of almost $\$ 1.5$ billion for the 2010 general election. According to the Mexican Federal Electoral Institute, $\$ 1$ billion was budgeted for 
Mexico's 2006 presidential election. Equally, the marketing of political candidates has become a multimillion dollar business in the past decade. According to $\mathrm{CNN}^{1}{ }^{1}$ more than $\$ 580$ million was spent on advertising by all political candidates and parties in the 2008 United States election. In comparison, according to TNS Media Intelligence, during the first quarter of 2010, the top five advertisers in the United States (Procter \& Gamble, AT\&T, General Motors, Verizon, and Pfizer) spent at least $\$ 400$ million each to promote their products and services. Considering that these companies advertise multiple brands or services, the $\$ 310$ million spent by then Democratic presidential nominee Barack Obama and $\$ 134$ million spent by Republican counterpart John McCain are considerable advertising budgets from any perspective. The marketing budgets of political candidates thus make it seem that now more than ever "political leadership... is driven not only by ideology but also by marketing" (Newman 1994:6).

With so much money involved and so much at stake-in terms of the influence exerted by the winning candidate on the future of the United States, and on the world in terms of economy and geopolitical positioning - trying to understand the market determinants of a presidential election in any country is now more than ever of great interest for politicians, political marketers, and marketing academicians. Furthermore, understanding voter behavior, such as how voters evaluate candidates and the voting shortcuts they take, has provided valuable insights for political marketing given the fact that voters, in general, do not share political commentators' and academics' fascination with politics (Harris and Lock 2010). This study thus focuses on the end consumerthe voter - to understand how the "political candidate brand" is evaluated and what role, if any, a voter's self-perception has on this evaluation.

Surprisingly, although candidates are commonly described by political and marketing analysts as brands in the popular press and blogosphere, the conceptualization of political candidates as brands has been sparsely discussed in academic literature (Nakanishi, Cooper, and Kassarjian 1974; Lott Jr. 1991; Hockett 2005; Guzmán and Sierra 2009; Phipps, Brace-Govan, and Jevons 2010). For example, Schneider (2004:46) states that "politicians who are strongly in the public eye, certainly do have a brand status." Although some authors have conceptually developed or empirically tested a political brand framework (e.g., Newman 1999; White and de Chernatony 2002; Schneider 2004; Reeves, de Chernatony, and Carrigan 2006; Smith 2009; Smith and French 2009; French and Smith 2010; Phipps et al. 2010), an exhaustive review of the relevant literature reveals that only Guzmán and Sierra (2009) have empirically developed a political candidate brand image framework using an established theoretical framework-Aaker's (1997) brand personality scale.

The concept behind viewing political candidates as brands says that voters facing a complex decision making scenario will resort to cognitively efficient strategies in order to simplify their task (Schneider 2004; Guzmán 
and Sierra 2009; Smith 2009; Smith and French 2009). The cognitive psychology and political science literature have confirmed that people generally create shortcuts whenever possible in order to simplify decision making. Research has demonstrated that consumers adopt simplifying strategies when facing complex problems (e.g., Payne 1976; Fisk and Taylor 1984), while political decision-making shortcuts employed by voters in evaluating a candidate based on his or her image and personal characteristics helps them decide how to vote (Popkin et al. 1976; Feldman and Conover 1983; Rosenberg and McCafferty 1987; Caprara, Barbaranelli, and Zimbardo 1997). In both the cognitive psychology and consumer behavior literature, a shortcut commonly discussed is self-referencing-encoding events in reference to the self (Brown, Keenan, and Potts 1986). Cognitive shortcuts are developed because people know more about themselves than about others; therefore, a more elaborate encoding of events can be made with respect to the self than to other schemata (Brown et al. 1986; Debevec, Spotts, and Kernan 1987). Self-referencing thus provides meaning to new stimuli and allows individuals to go beyond the currently available information in order to make decisions (Markus 1977; Rogers, Kupier, and Kirker 1977). In a political marketing setting, self-referencing could be understood as the process voters go through when evaluating a political candidate based on the congruity between the candidate and a voter's own characteristics.

The motives, perceptions, and intention of voters have been studied in the past, generally based on Newman and Sheth's (1985) model of voter behavior. However, there appears to be a paucity of research investigating whether the notion of self influences the way a voter evaluates a political candidate brand and, if so, how. In order to answer these questions, and in response to Henneberg and O'Shaughnessy's (2007) call for more quantitative research in political marketing, the following study examines how perceptions of political candidates are influenced by an individual's concept of self. Aaker's (1997) brand personality scale is used to evaluate candidate brand image perception, and the same scale is applied to consistently measure voters' perception of self, here termed self-brand image. Using data from a nationwide research study that measures the self-brand image of Mexicans and the brand image of presidential candidates in Mexico's 2006 election, the study tests whether people see themselves and each candidate as a distinct brand and whether this view of their self-brand has any influence over their perception of a political candidate's brand image.

The next section of this paper provides a review of the political marketing literature as well as literature pertaining to self-referencing and brand image. The third section discusses the research method, while the fourth section presents the results. The final section of this article discusses the study's academic and managerial implications, its limitations, and directions for future research. 


\section{THE CURRENT STATE OF POLITICAL MARKETING}

Although political marketing only became a serious research focus in the 1990s (Henneberg and O'Shaughnessy 2007), academic literature on how modern marketing practices could be applied to political campaigns started to emerge in the mid 1970s. By that time it was already argued that political marketing had developed into a marketing concept orientation in which the consumers' (voters') needs and wants were identified, and then considered, by political marketing practitioners to develop a primary focus for a campaign (Shama 1976; Newman 1994; O'Cass 1996). From the start, when analyzing the similarities between goods and services and political marketing, the political candidate was viewed as the product while the political party was viewed as a brand (Shama 1976). The reasoning was that people viewed political parties as the logical cognitive shortcut on which to base their decisions (Schneider 2004). For a while, political marketing literature adopted this conceptualization (Lock and Harris 1996; Smith 2001; White and de Chernatony 2002; Needham 2006) with no one really questioning it. Recently, however, some authors have begun to recognize that politicians as well as political parties function as brands (Schneider 2004; Guzmán and Sierra 2009; Smith 2009; French and Smith 2010). Schneider (2004:54) reports that political brands serve an informational efficiency, risk-reducing, and sentimental utility function to voters and "that political brands exert a significant impact on the formation of political preferences." Phipps et al. (2010) take this analysis a step further and consider the politician to be a brand influenced by the corporate brand of their political party. The increased relevance and influence of political brands over individuals' voting decisions is strengthened by the fact that modern politics has turned into perception politics and thus political marketing into political impression management (De Landtsheer, De Vries, Vertessen 2008).

Newman and Sheth (1985) developed a model of voter behavior driven by seven cognitive domains: issues and policies, social imagery, emotional feelings, candidate image, current events, personal events, and epistemic issues. This model, tested in the early 1980s, revolves around the voter's perception of the candidate and serves as a first hint to understanding that candidates were being viewed by voters as brands. The researchers found that issues, policies, and social imagery were the variables that dominated the model (Newman and Sheth 1985). Moreover, Rosenberg and McCafferty (1987) demonstrated that the candidate's personal qualities and image, apart from their political parties or issue positions, significantly influence voters' perceptions and preferences. Even though some politicians and political candidates have become extremely popular, and built or attempted to build a marketable image and brand of their own (Bachelet, Bloomberg, Bush, Chavez, Clinton, Giuliani, McCain, Obama, Palin, Sarkozy, etc.), only a few 
authors have explicitly referred to political candidates as brands (e.g., Nakanishi et al. 1974; Lott Jr. 1991; Hockett 2005; Guzmán and Sierra 2009; Smith 2009; Phipps et al. 2010). In agreement with Guzmán and Sierra (2009), it is posited here that as the image of the candidate has become more important, voters' simplification processes have shifted from focusing on parties to focusing on the candidates. Although this shift in focus might be less pronounced in parliamentarian systems such as in Britain or Spain (Davies and Mian 2010), it is clearly present in a federal constitutional republic system, such as in the United States and in Mexico. That said, an example of a political candidate as an individual brand and a political party as a brand in a parliamentarian system can be found in the politics of India. The Congress party of India is a party brand that people identify with and vote for. Notwithstanding, members of the Nehru-Gandhi family (J. L. Nehru, Indira Gandhi, Rajiv Gandhi, Rahul Gandhi) are members of the Congress party but are also powerful individual brands in their own right. However, Varun Gandhi (grandson of Indira and son of Sanjay Gandhi) joined the opposition Bharatiya Janata Party and is not seen as such a high powered brand. This synergy between the party brand and the individual candidate brand, according to Phipps et al.'s (2010) political brand conceptualization, is an example of a party playing the role of a corporate brand to which the political candidate brand is associated. While this may be the case in the parliamentary system of Indian, our research focuses on the candidates as brands in a federal constitutional republic system and therefore is positioned to analyze how much self-referencing influences the voter's perception of a political candidate brand image.

\section{SELF-REFERENCING}

Self-schemata or self-references "are cognitive generalizations about the self, derived from past experience, that organize and guide the processing of self-related information contained in the individual's social experiences" (Markus 1977:64). The concept of self "refers to a complex, unitary activity of sensing, remembering, imagining, perceiving, wanting, feeling, and thinking" (Bertocci 1945:91). Rogers et al. (1977:677) informally define the self as "the abstracted essence of a person's perception of him or herself." Epstein (1973) suggests that individuals use their self-concept to make sense of the world. In psychoanalytic terms, the sense of the self is derived by an individual as an infant when first able to identify an image in a mirror as oneself (Lacan 2001). This "mirror stage" of one's evolution has a lasting effect on psychological development because the relationship between the ideal-I and the infant is the foundation for future social relationships and self-image (Lacan 2001). Placing that in a political context, self-referencing serves as a mediator between individuals' perceptions and the visual and 
verbal stimuli (Debevec and Romeo 1992) to which they are exposed by candidates' marketing communications efforts, including advertising and public appearances. In other words, individuals selectively encode information based on their previous experience and knowledge, affecting what they notice, learn, remember, and infer (Markus 1977) and, consequently, their ensuing attitudes and intentions (Debevec and Romeo 1992). Additionally, it has been demonstrated that self-referencing is a potent encoding device (Rogers et al. 1977) that enhances memory (Brown et al. 1986). Thus, individuals who self-reference information are able to learn and recall information better than those who do not (Debevec and Romeo 1992).

In marketing, self-referencing has been shown to have an effect on persuasion, an instrumental role in consumers' response to communications stimuli (Debevec et al. 1987). As a consequence, advertising frequently tries to evoke past personal experiences (Sujan, Bettman, and Baumgartner 1993) in an effort to influence consumer behavior. Political candidates also rely on this method as a way to connect with the electorate in a more personal way. Sujan et al. (1993) find that self-referencing leads to higher levels of felt affect and reduced analysis of product attributes, enhancing ad and brand evaluations. This effect, however, may hurt learning about the advertisement or brand because the emotional attachment created by the message may lead consumers to truncate their evaluation. Burnkrant and Unnava (1995) argue that when individuals are exposed to a strong message, self-referencing leads to an increase in persuasion, as long as the message is simple. However, when a message leads to more critical argumentation, the positive effect of self-referencing over persuasion is undermined or reversed (Burnkrant and Unnava 1995). Meyers-Levy and Peracchio (1996) further elaborate Burnkrant and Unnava's (1995) findings by showing that, in fact, an initial moderate increase in self-referencing enhances persuasion while a more extreme increase undermines it. Nevertheless, they find that consumer motivation toward the ad or the brand mediates this effect. If no motivation is present, self-referencing has no effect whatsoever (Burnkrant and Unnava 1995).

It is the position of this paper that because political candidates' messages are, in general, not simple, people facilitate their voting decisions by concentrating on the candidates' images (Miller, Wattenberg, and Malanchuk 1986; Rosenberg et al. 1986; Sigelman et al. 1986; Gopoian 1993). As such, self-referencing becomes a convenient cognitive structure for voters to rely on when analyzing a simplified version of the political scenario where candidates are viewed as brands. Voters will ask themselves questions such as: "Do I relate to this candidate?" and "How much does this candidate resemble who I am?" Given that motivation will normally be present when deciding which political candidates to vote for, according to Meyers-Levy and Peracchio's (1996) findings we can predict that 
self-referencing will influence voters' perception of the brand image of the candidate they prefer.

\section{A BRAND/SELF IMAGE MEASUREMENT}

Brand personality was originally defined as "the set of human characteristics associated with a brand" (Aaker 1997:347). As consumers perceive brands to have a certain personality, which recapitulates all the benefits and values it represents, the analysis of brand personality has gained importance given its influence over brand positioning. Consumers will have a more favorable attitude toward brands that match their own personality (Bosnjak, Bochmann, and Hufschmidt 2007). By self-referencing, individuals evaluate their consumption decisions based on the set of values a brand has and its compatibility to their own set of values. Thus, the use of brand personality can turn into a self-referencing tool that facilitates consumption decisions.

Aaker's (1997) brand personality scale has been heavily scrutinized for research in political marketing in terms of its generalizability (Austin, Sigauw, and Matilla 2003; Supphellen and Grønhaug 2003; Bosnjak et al. 2007) and validity (Smith 2009). Brand personality is only one of several dimensions that configure brand image or identity (Plummer 1984/1985; Keller 2003; Kapferer 2004). It has been argued that Aaker's scale encompasses attributes that go beyond personality (Davies et al. 2001; Azoulay and Kapferer 2003; Guzmán and Sierra 2009) and includes physical, intellectual, and social class characteristics. Aaker's scale has also been scrutinized for its lack of cross-cultural applicability (Ferrandi, Valette-Florence, and Fine-Falcy 2000; Aaker, Benet-Martínez, and Garolera 2001; Smit, van den Berge, and Franzen 2002) and its lack of negative items (Bosjnak et al. 2007; Guzmán and Sierra 2009; Kaplan et al. 2010). Furthermore, Ferrandi and Valette-Florence (2002) argue that the scale is not transposable for measuring human personality.

Conversely, researchers such as Azoulay and Kapferer (2003), Bosnjak et al. (2007), Davies et al. (2001), and Guzmán and Paswan (2009) argue that the broader conceptualization of brand personality behind Aaker's (1997) scale allows for its utilization as a measurement of brand image. The use of Aaker's (1997) scale is appropriate for measuring brand image in this study for three primary reasons. First, researchers consider the scale suitable for measuring brand image (Davies et al. 2001; Azoulay and Kapferer 2003; Guzmán and Sierra 2009) because it includes items that measure characteristics beyond personality. Second, no specific brand personality or brand image scale has been developed for the Mexican market. And third, although brand personality and self-congruity as empirically discriminant constructs "should not be discussed or measured interchangeably" (Hegleson and Supphellen 2004:226), we are measuring brand image and self-brand image 
rather than brand or candidate personality and self-congruity. This is also the reason we did not consider Goldberg's (1990) Big Five human personality scale as a measure.

\section{HYPOTHESES}

With this as an underlying framework, Aaker's (1997) brand personality scale with its five dimensions - sincerity, excitement, competence, sophistication, and ruggedness - is used as a measure of the political candidates' brand image. In order to create consistency between the measures of brand image and self-brand image, the same 42 scale items are used to measure voters' self-brand image. These 42 items capture five dimensions: sincerity (down-to-earth, family oriented, small-town, honest, sincere, real, wholesome, original, cheerful, sentimental, friendly); excitement (daring, trendy, exciting, spirited, cool, young, imaginative, unique, up-to-date, independent, contemporary); competence (reliable, hard working, secure, intelligent, technical, corporate, successful, leader); sophistication (confident, upper class, glamorous, good looking, charming, feminine, smooth); and ruggedness (outdoorsy, masculine, western, tough, rugged). Guzmán and Sierra's (2009) and Phipps et al.'s (2010) view that a candidate's image is becoming the main focus of a voter's simplification processes in order to make an electoral decision leads us to predict that a consumer (voter) views each political candidate as a unique brand different from his or her perception of self. We thus believe that people view their self-brand image as distinct to each political candidate brand image. In other words, individuals will perceive themselves differently on each of the brand image dimensions: sincerity, excitement, competency, sophistication, and ruggedness. Or, as Lacan (2001) would argue, recognition happens through visuality and spatiality because individuals strive for identification with an image and alienation from it. The following hypothesis captures this expectation:

H1: Voters will discriminate between political candidates and their individual self-brand on each of the five brand image dimensions in an effort to develop a separate brand image for each candidate.

Furthermore, Meyers-Levy and Peracchio's (1996) finding that self-referencing enhances persuasion only if there is a certain degree of consumer motivation toward the brand leads us to predict that perceived self-brand image (self-referencing) will have an effect on voters' perception of the candidates' brand image. Similar thoughts have been suggested by Aspara et al. (2008) in their conceptualization of affective self-affinity. We thus assume that voters will look for congruence between their perceived self and the candidate. In other words, we assume that individuals will perceive 
their preferred candidate's brand image as more similarly sincere, exciting, competent, sophisticated, and rugged to how they perceive themselves. The following hypothesis captures this expectation:

H2a: There will be congruence between the different dimensions a political candidate's brand image and the corresponding dimension of a voter's self-brand image.

H2b: Such congruence is likely to be a predictor of success in the actual election.

\section{RESEARCH METHOD}

The hypothesized relationships were tested using a national household survey research design. A random sample representative of Mexican registered voters was surveyed between March 11 and 17, 2006. The sample was selected in multiple stages based on the Mexican Federal Electoral Institute's numerical list of voters in each state. The survey was administered in all 32 Mexican states and in 88 different locations for which households were chosen systematically. Individuals were selected by random sample based on sex and age allowing for representativeness of Mexico's voting population. A door-to-door survey method was used to contact the respondents. Only one person in each household responded to the questionnaire according to the sampling method. From a total of 1,144 administered surveys, the final usable sample included 1,089 respondents. The demographic characteristics of the sample are presented in Table 1.

The respondents were asked to evaluate on a 5-point Likert-type scale ( $1=$ not at all descriptive and $5=$ extremely descriptive) their self-brand image and the brand image of the three principal presidential candidates in Mexico's 2006 election-Felipe Calderón Hinojosa (candidate A), Andrés Manuel López Obrador (candidate B), and Roberto Madrazo Pintado (candidate C) based on the 42 items from Aaker's (1997) brand personality scale. Although

TABLE 1 Sample Demographic Characteristics

\begin{tabular}{|c|c|c|c|c|c|c|c|c|c|}
\hline \multicolumn{2}{|l|}{ Age } & \multicolumn{2}{|c|}{ Sex } & \multicolumn{2}{|c|}{ Level of education } & \multicolumn{2}{|c|}{ Occupation } & \multicolumn{2}{|c|}{ Class considered } \\
\hline Min & 18 & Male & $51.00 \%$ & None & $6.29 \%$ & $\begin{array}{l}\text { Private } \\
\quad \text { Company }\end{array}$ & $16.02 \%$ & Low & $27.03 \%$ \\
\hline $\operatorname{Max}$ & 87 & Female & $49.00 \%$ & Elementary & $37.10 \%$ & Public Sector & $6.17 \%$ & Mid-low & $31.38 \%$ \\
\hline Mean & 40.14 & & & $\begin{array}{l}\text { Middle } \\
\text { School }\end{array}$ & $25.17 \%$ & Freelance & $28.94 \%$ & Middle & $36.86 \%$ \\
\hline \multirow[t]{2}{*}{ StdDev } & 15.43 & & & $\begin{array}{l}\text { High } \\
\text { School }\end{array}$ & $20.22 \%$ & Student & $5.65 \%$ & Mid-High & $2.44 \%$ \\
\hline & & & & University & $11.20 \%$ & $\begin{array}{l}\text { Housewife } \\
\text { Retired/ } \\
\quad \text { Unemployed }\end{array}$ & $\begin{array}{r}34.08 \% \\
9.11 \%\end{array}$ & High & $0.43 \%$ \\
\hline
\end{tabular}


Bosnjak et al. (2007) argued to include negatively balanced items, all of the traits were kept as positively balanced, given that Article 38 of the Mexican Federal Electoral Procedures and Institutions Code prohibits the use of negative descriptions in electoral surveys. Because all respondents were Spanish speakers, the scale items were translated to Spanish and then back-translated to English to ensure the integrity of meaning of the scale items. The order of the candidates and scale were randomly rotated to avoid primacy and recency effects.

\section{ANALYSIS AND RESULTS}

The scales were first checked for internal consistency (see Table 2). The results indicate that Aaker's (1997) brand personality scale items measuring sincerity; excitement; competence; sophistication, and ruggedness for the three political candidates and the self-brands have acceptable levels of internal consistency (Nunnally 1978). Composite scores were created (by averaging the scale items) for each brand image dimension for the three candidates and the self-brands for further analysis. These composite scores were used to compute the inter-factor correlations across the three political candidates and the self-brands. The results show that the inter-factor correlations within a brand (political candidates $\mathrm{A}, \mathrm{B}$, and $\mathrm{C}$ and self) are consistently higher than across brands (see Table 2). These suggest that respondents discriminate among the three political candidates and their self-brand on each of the five brand image dimensions.

To test the first hypothesis, the average scores for each brand image dimension were compared across the three political candidates and the self-brand using ANOVA (see Table 3). By and large, respondents' scores were significantly higher $(p<.05)$ on all dimensions of self-image than their scores for the three political candidates (candidate B seems to fare better than A, followed by C). These further confirm that respondents discriminate between themselves and political candidates on the five brand image dimensions. One interesting finding is that while evaluating their self-brand, respondents scored highest on the sincerity dimension followed by the competence and excitement dimensions. However, they only gave the third highest score to all political candidates on the sincerity dimension. The dimension on which political candidates were best evaluated was competence. Moreover, candidates $\mathrm{A}, \mathrm{B}$, and $\mathrm{C}$ were perceived similarly (ANOVA post hoc analysis) on the sophistication dimension, and candidates $\mathrm{A}$ and $\mathrm{C}$ were similarly evaluated (ANOVA post hoc analysis) on the ruggedness dimension. This evidence provides support for hypothesis 1: Voters evaluate candidates and self based on brand dimensions and see themselves as distinct from each candidate's brand. The mean scores for the political candidate and self-brand on the five dimensions are presented in Figure 1. 


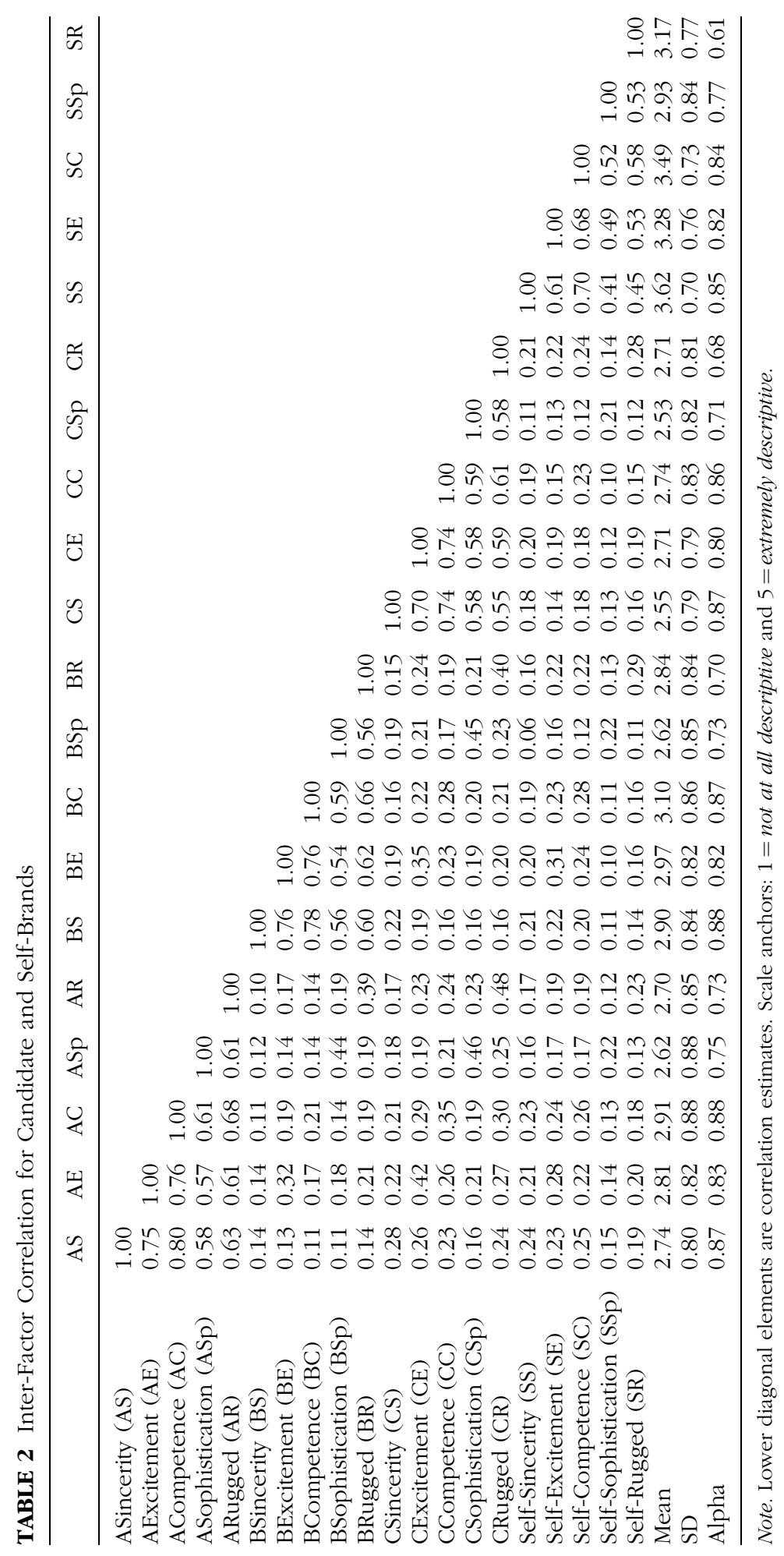




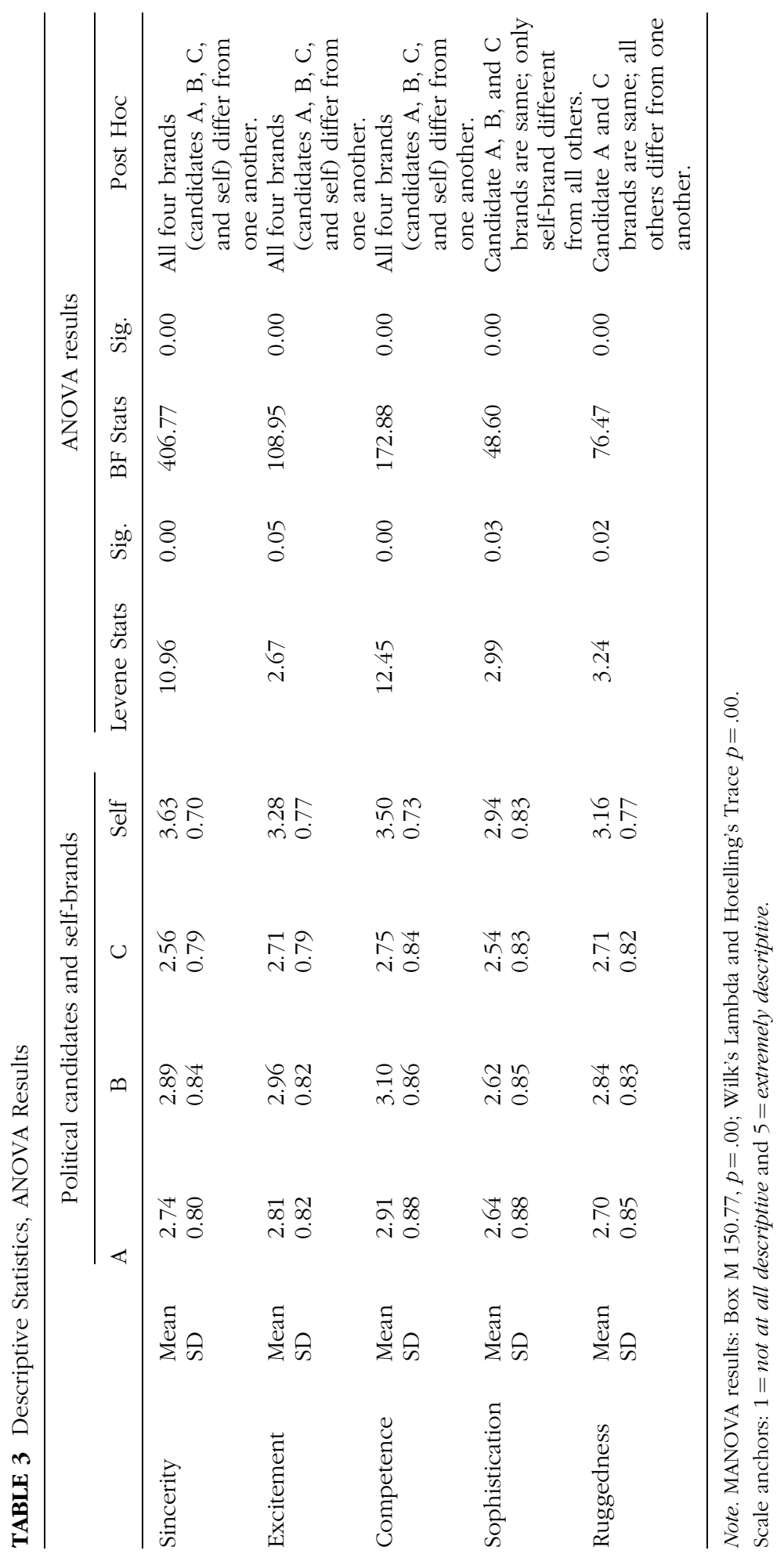




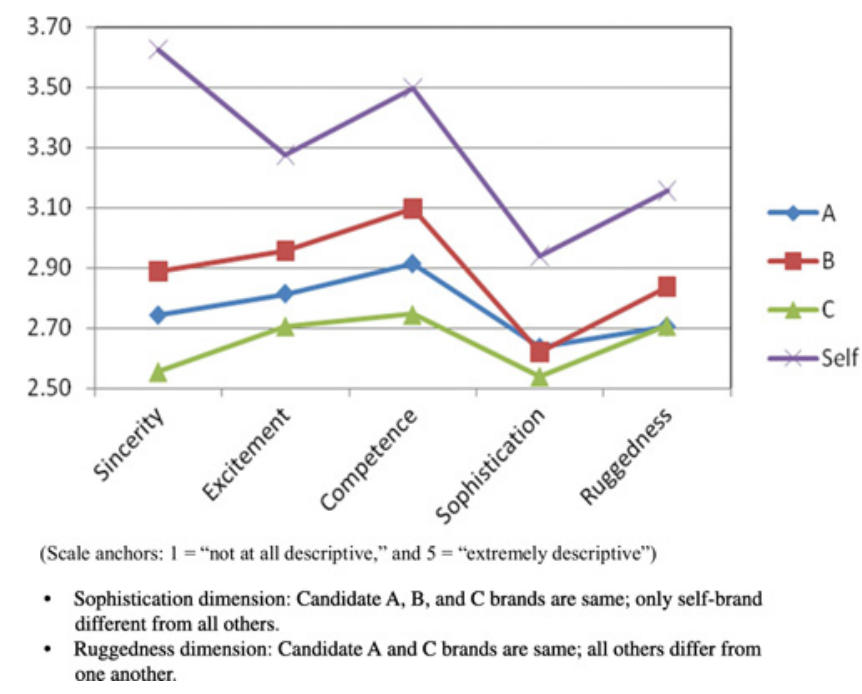

FIGURE 1 Image of self-brand versus political candidate brands (A, B, and C): ANOVA plot.

In order to determine whether there is support for the second hypothesis, a series of regression analyses (see Table 4) were first used to get a sense of the relationship between the dimensions of self-brand with the corresponding dimensions of political candidate brands. Next, a multidimensional scaling (MDS) procedure (see Figure 2) was used to see a more holistic picture of the congruence between the composite scores for the dimensions capturing the self and political candidate brands image.

The results of the multiple regression analyses indicate that self-sincerity is associated with the sincerity dimension for candidates $\mathrm{A}, \mathrm{B}$, and $\mathrm{C}$; the excitement dimension for candidate $\mathrm{C}$; and the sophistication dimension for candidate B. Self-excitement is associated with the excitement dimension for candidates A, B, and C; the sincerity dimension for candidate B; the competence dimension for candidates $\mathrm{A}$ and $\mathrm{B}$; the sophistication dimension for candidate B; and ruggedness dimension for candidates $\mathrm{A}$ and $\mathrm{B}$. Self-competence is associated with the competence dimension for candidates A, B, and C and the sincerity dimension for candidate A. Self-sophistication is associated with the sophistication dimension for candidates A, B, and C; the excitement dimension for candidate $\mathrm{B}$; and the ruggedness dimension for candidates B and C. Finally, self-ruggedness is associated with the ruggedness dimension for candidates $\mathrm{A}, \mathrm{B}$, and $\mathrm{C}$ and the excitement dimension for candidate C.

Further, the results of the multiple regression analyses indicate that candidate $\mathrm{B}$ has the most number of significant beta weights between its brand image dimensions and the self-brand image dimensions (a total of 12 significant associations in comparison to candidates $\mathrm{A}$ and $\mathrm{B}$, which only had 8 


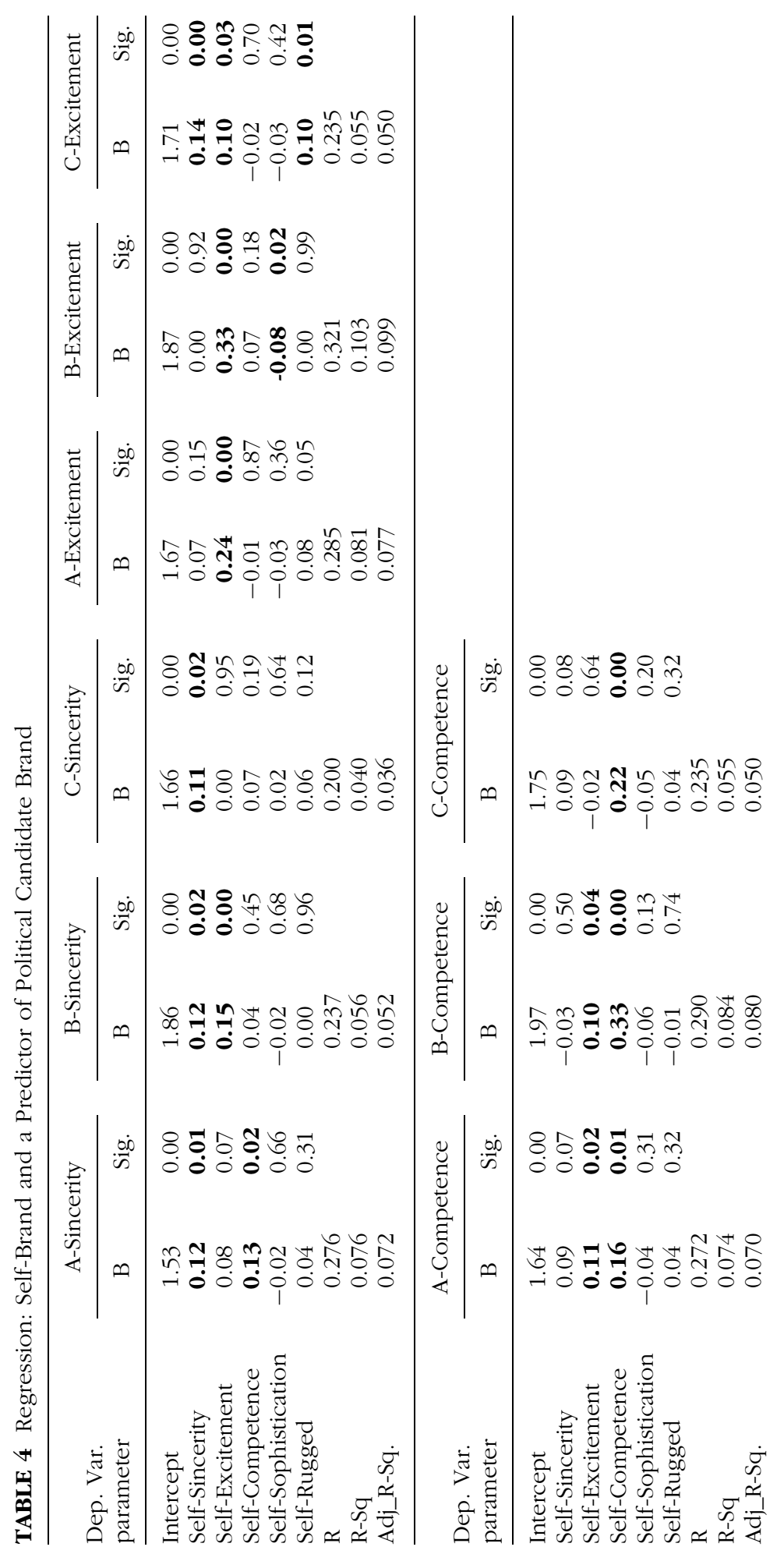




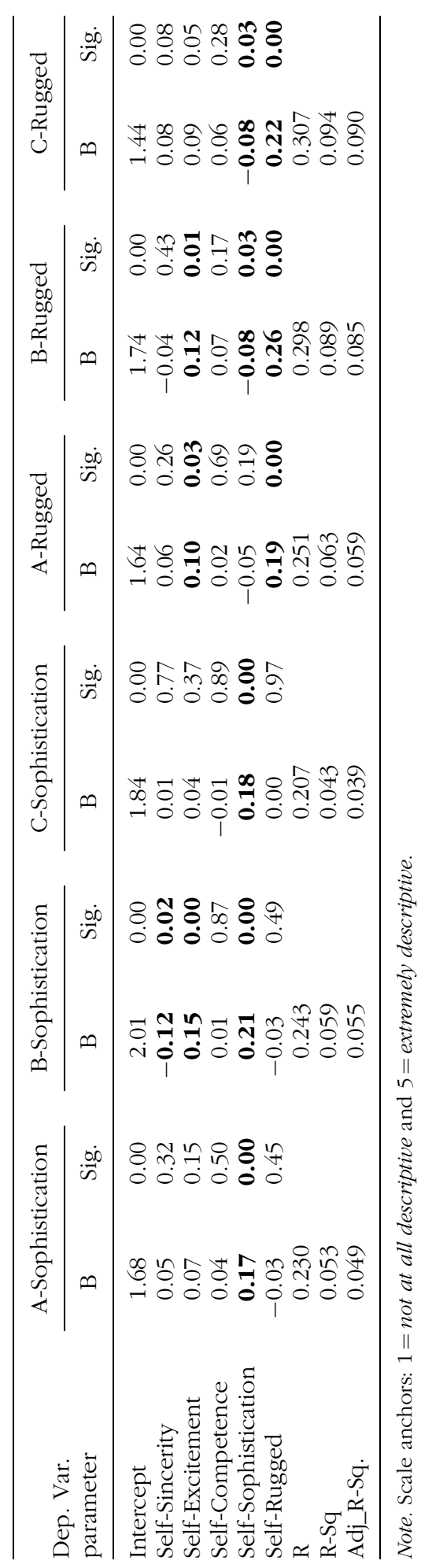




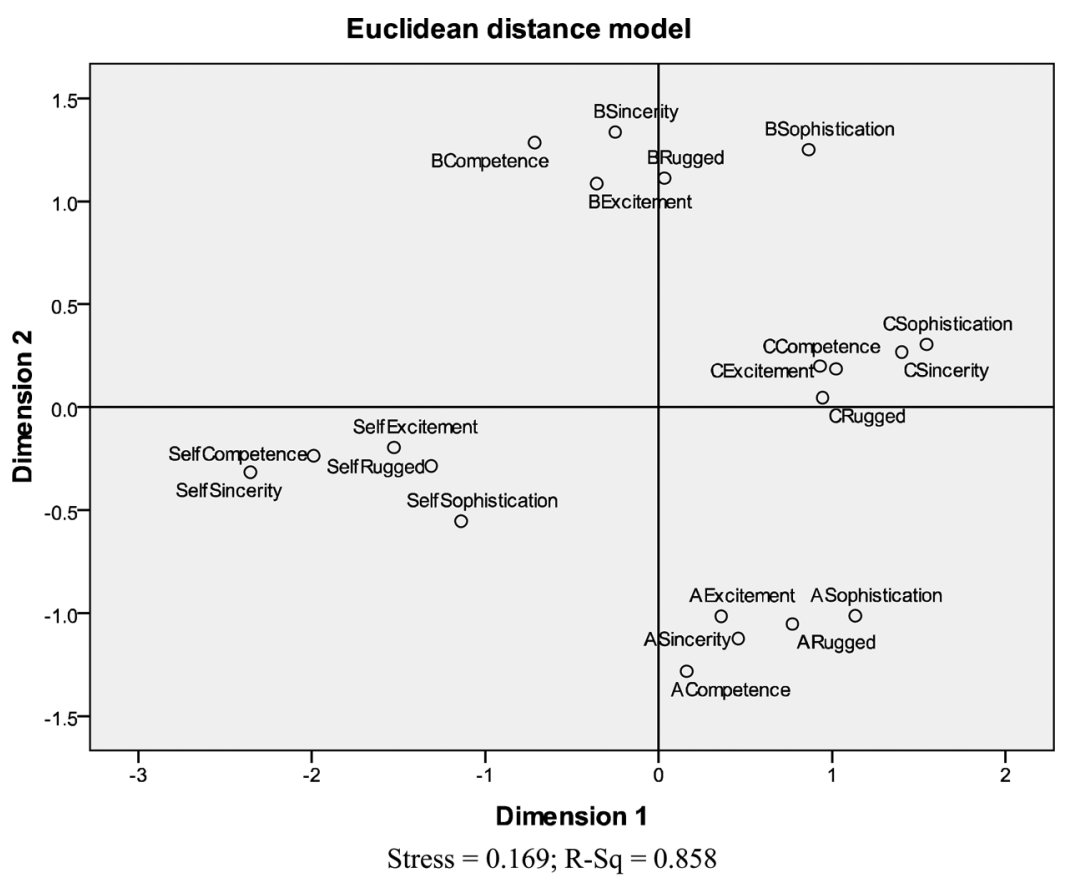

(Scale anchors: 1 = "not at all descriptive," and $5=$ "extremely descriptive")

FIGURE 2 MDS model of self-brand versus political candidate brands (A, B, and C).

significant associations each). This evidence provides support for hypothesis 2a: There is congruence between the different dimensions a political candidate's brand image and the corresponding dimension of a voter's self-brand image.

Given our intention to identify our study as purely academic, in contrast to the many opinion polls that were being conducted at that time, we did not measure the respondent's preference for a political candidate. However, we did have access to the results of several independent political polls conducted around the same time when the data for this study were collected. The results of these polls showed López Obrador (candidate B) with a 10-point lead. This may suggest that a candidate who is evaluated more similarly to how the voters evaluate themselves could be the preferred candidate. In order to get a more holistic picture, we used the composite (averaged) factor scores in a multidimensional scaling (MDS) analysis (see Figure 2).

MDS is "an exploratory technique to identify unrecognized dimensions affecting behavior, and a means of obtaining comparative evaluations of objects when the specific bases of comparison are unknown or undefined" (Hair et al. 2010:552). In other words, the purpose of MDS is to provide a visual representation of the pattern of proximities (i.e., similarities or distances) among a set of objects. MDS has its origins in psychometrics, where it was 
proposed to help understand people's judgments of the similarity of members of a set of objects (Richardson 1938; Torgerson 1952). MDS has been used in such diverse fields as marketing, sociology, physics, political science, and biology (Young and Hamer 1994).

The results of the MDS analysis (Figure 2) indicate that the four brands (candidates A, B, and C and self-brands) are internally consistent within and are seen as distinct from one another and the model has acceptable fit indices (stress $=.169$ and $R^{2}=.858$ ). Candidates $\mathrm{A}$ and $\mathrm{B}$ seem to lie furthest apart from one another along the same dimension, while candidate $\mathrm{C}$ is positioned orthogonally from both candidate A and B, but diametrically different from the self-brand. Further, although ANOVA results indicated the candidate B to be second highest (after the self-brand) in terms of voter rating on the five dimensions, the MDS plot suggests a slightly different picture. Although the visual plot of the three political candidates and the self-brand indicates that the self-brand is more or less equidistant from both candidate A and B, candidate A seems somewhat closer to self-brand (at least on dimension 2) than candidate B. Interestingly, the winning candidate of the 2006 election was not candidate B but candidate A, Felipe Calderón. Thus, together, the results of the regression analyses and MDS suggest that the congruence among the different dimensions of a voter's self-brand image and the dimensions of political candidate's brand image seems to be higher for the preferred candidate. This evidence provides support for hypothesis 2b: Congruence between the different dimensions a political candidate's brand image and the corresponding dimension of a voter's self-brand image is likely to be a predictor of success in the actual election.

\section{DISCUSSION AND IMPLICATIONS}

The objective of this study was to empirically test whether people view political candidates as brands and analyze whether self-brand image influences a voter's perception of a political candidate brand. Using data from a nationwide research study conducted in March 2006 that measured the self-brand image of Mexicans and the brand image of presidential candidates in Mexico's 2006 presidential election, it was possible to find strong support for both of the study's hypotheses. The findings suggest that Mexican voters do perceive political candidates as brands that are distinct from each other and distinct from their own self-brand image. Interestingly, Mexican voters viewed themselves as more sincere, more exciting, more competent, more sophisticated, and more rugged than any of the political candidates that were running for president that year. Results also suggest that Mexican voters consider sincerity to be their strongest brand characteristic, while that particular dimension is only the third most relevant characteristic they perceive political candidate brands possess. It is in terms of competence that the political 
candidate brands fare best. For each individual political candidate brand, competence was perceived to be the strongest trait. All of these findings could provide important insights to political strategists as they work to identify the appropriate candidates and develop their brand strategies for subsequent elections.

In terms of the effect that the concept of self has on the evaluation of the political candidate brands, our results suggest there is a clear correlation between the way voters view themselves and the way they view political candidates. Our findings reveal that candidate B, Andrés Manuel López Obrador, had the highest number of significant associations between dimensions of his brand image and the dimensions of the voters' self-brand images. Interestingly, at the time the data were collected, López Obrador had a 10-point lead across several polls. This may suggest that a candidate who is evaluated by voters as more similar to the voters themselves has a better chance of being elected. This line of thinking is consistent with the research on affective self-affinity, which is a result of the overlap between the identity attributes of what's being evaluated and the personal identity attributes of whomever is evaluating (Dutton, Dukerich, and Harquail 1994; Scott and Lane 2000; Marin and Ruiz 2007; Aspara et al. 2008). Relying on this literature and the results of our study, we suggest that the higher the level of congruence (or overlap) between the self-brand image dimensions and the political candidate's brand image dimensions (multipoint congruence), the higher the likelihood of affective self-affinity developing between self and the political candidate, and consequently, the higher the intention to vote (reflected in higher rating points for López Obrador at the time of this study). Unfortunately, due to the study's complexity and the difficulty and high cost of replicating it at a national level, it was not possible to obtain additional data closer to the election. The winning candidate of the 2006 election was not candidate B but candidate A, Felipe Calderón. It would have been valuable to know whether the level of congruence between his brand image dimensions and the voters' self-brand image dimensions converged toward the end of the electoral campaign as the electoral race shifted in his favor.

Regarding each of the political candidate brands, it is interesting to see how their political pasts may have influenced their perceived brand image among Mexican voters. For example, candidate C, Roberto Madrazo, has the lowest scores on all of the dimensions except for ruggedness. The fact that Madrazo was perceived as more rugged than Calderón could very well have been due to the fact that he was governor of Tabasco, a southern state of Mexico, and was considered to have strong political will and a tough style as he confronted major oil union unrest. Likewise, Calderón, from the conservative party, became known as a strong negotiator after many years of work in Congress, and as such his style was seen as less confrontational and thus his evaluation as less rugged. This could also be explained by the fact that he may have been seen as more of a technocrat because he attended 
a private university and received one of his undergraduate degrees in the United States. Conversely, López Obrador was perceived as less sophisticated than Calderón. This may be because López Obrador represented the popular vote during this election, relied on a grassroots effort directed to the poorest population of the country, and built a political platform that emphasized his humble origins and his connection to the poor. Other than these two dimensions, López Obrador was evaluated higher than Calderón, who was rated higher than Madrazo. As previously mentioned, these perceptions of each of the candidates' brand image could very well be a reflection of who people felt more identified with at that time and who they would have voted for if the election had been held in mid-March.

Furthermore, this study has important implications for both academicians and practitioners. From an academic perspective, our findings would suggest that given the fact that voters nowadays focus more on the candidate than on the party (i.e., candidates have become more powerful brands than political parties), academics must reframe how they look at political marketing research. We believe that political brand research should adopt Phipps et al.'s (2010) conceptualization of a political brand in which the candidate is perceived as a brand and the party as a corporate brand. Future research on political branding should explore this relationship in more depth in hopes that once and for all the political branding discussion converges into one single conceptualization, even in parliamentarian systems. From a practitioner perspective, our findings serve to confirm the direction that it seems political marketing has taken in recent years. Our findings provide support for developing branding strategies for political candidates based on the understanding of how they are currently perceived by voters. In other words, campaign strategists should focus on making sure that a candidate's brand identity model is consistent throughout every single one of its touchpoints with voters. Understanding a candidate's brand image and how he or she fares against its opponents on each dimension serves as a solid platform for this analysis. Although Smith (2009) found that Aaker's brand personality framework was not valid for political brands in the UK, this study demonstrates that the model does work in a Mexican context. The difference in results could be due to the fact that Smith's (2009) study focused on analyzing political parties as brands instead of the candidates or given the aforementioned difference of political systems in which both studies were conducted. It is our opinion that until other models are applied or developed in order to evaluate political candidate brand image, Aaker's (1997) model is an adequate tool for this endeavor. In summary, given that the increased relevance and influence of political brands over individuals' voting decisions is strengthened by the fact that modern politics has turned into perception politics and thus political marketing into political impression management (De Landtsheer et al. 2008), our findings suggest that practitioners must go into an election thinking exclusively about what can help build their candidate's brand over just about anything else. 


\section{CONCLUSION}

A key limitation of this study is that its sampling frame is limited to Mexico. Future studies should explore whether the findings hold true in other countries and political systems. For example, testing whether self-brand image influences the perception of a political candidate brand image should be conducted in a country with a parliamentarian system in which its citizens vote for a party instead of a candidate. It would also be interesting to see whether self-brand image in other countries is also stronger than the candidates' brand image or whether this result is particular to a high level of self-esteem of Mexican voters. This result was particularly surprising as we would have expected, at least in terms of competence (the strongest trait for all candidates), that the candidates would have been better evaluated. In other words, future studies could test for cross-cultural differences in how and to what extent self-referencing is used to make electoral decisions. Another limitation of this study, as mentioned in the method section, is the impossibility of including negative descriptors of the candidates in the scale items given the prohibition by federal laws. Including negative descriptors to evaluate brands could have an interesting effect not only on how people evaluate the candidate brands but also on how they evaluate their self-brand. Future research could explore whether the incorporation of negative traits in the evaluation of the brands confirm or refute the findings of this study. Finally, an important limitation to this study and the interpretation of its results was that we did not ask respondents about their political preferences or party affiliation. Given the complicated electoral scenario that existed in Mexico in 2006, it was our intention to clearly identify this research as academic and not ask this question in order to obtain the "purest" responses in an effort to directly address the study's research questions. Future studies should, if possible, ask for voting intention or party affiliation to test whether either affects the self-brand image influences on the perception of the preferred candidate's brand image.

This study's results serve to confirm what marketing analysts have been discussing for years - that the marketing of a political candidate brand has become a complex and consumer-driven strategy. A good example of this is the praise the Obama campaign received from the marketing world. In an editorial published the day after the 2008 United States election, branding and positioning expert Al Ries (2008:1) stated "Nov. 4, 2008 will go down in history as the biggest day ever in the history of marketing." This suggests that political branding has as much to learn from traditional branding as traditional branding has to learn from political branding. In other words, in order to bridge the gaps between consumers/voters and what the candidate brand represents to them, and given voter's general inclination to evaluate political candidates based on their image, candidates might be better off 
relying on political strategists that are more pure marketers rather than political advisors in order to integrate their political agenda as part of their brand image instead of vice versa.

We hope that the results of this study provide encouragement for further research investigating political candidate brands and the influences that affect how voters perceive them. It is our belief that in future elections around the world the power of the candidate brands will be increasingly evident, and we thus hope and expect that political branding becomes a central topic in the political marketing debate.

\section{NOTE}

1. http://www.cnn.com/ELECTION/2008/map/ad.spending/index.html.

\section{REFERENCES}

Aaker, J. L. (1997). Dimensions of brand personality. Journal of Marketing Research, 34(3), 347-356.

Aaker, J. L., V. Benet-Martínez, and J. Garolera. (2001). Consumption symbols as carriers of culture: A study of Japanese and Spanish brand personality constructs. Journal of Personality and Social Psychology, 81(3), 492-508.

Aspara, J., R. Olkkonen, H. Tikkanen, J. Moisander, and P. Parvinen. (2008). A theory of affective self-affinity: Definitions and application to a company and its business. Academy of Marketing Science Review, 12(3), 1-37.

Austin, J. R., J. A. Siguaw, and A. S. Mattila. (2003). A re-examination of the generalizability of the Aaker brand personality measurement framework. Journal of Strategic Marketing, 11(2), 77-92.

Azoulay, A., and J. N. Kapferer. (2003). Do brand personality scales really measure brand personality? Journal of Brand Management, 11(2), 143-155.

Bertocci, P. A. (1945). The psychological self, the ego, and personality. Psychological Review, 52(2), 91-99.

Bosnjak, M., V. Bochmann, and T. Hufscmidt. (2007). Dimensions of brand personality attributions: A person-centric approach in the German cultural context. Social Behavior and Personality, 35(3), 303-316.

Brown, P., J. M. Keenan, and G. R. Potts. (1986). The self-reference effect with imagery encoding. Journal of Personality and Social Psychology, 51(5), 897-906.

Burnkrant, R. E., and H. R. Unnava. (1995). Effects of self-referencing on persuasion. Journal of Consumer Research, 22(1), 17-26.

Caprara, G. V., C. Barbaranelli, and P. G. Zimbardo. (1997). Politicians' uniquely simple personalities, Nature, 385, 493.

Davies, G., and T. Mian. (2010). The reputation of the party leader and the party being led. European Journal of Marketing, 44(3/4), 331-350.

Davies, G., R. Chun, R. Vinhas da Silva, and S. Roper. (2001). The personification metaphor as a measurement approach for corporate reputation. Corporate Reputation Review, 4(2), 113-127. 
Debevec, K., and J. B. Romeo. (1992). Self-referent processing in perceptions of verbal and visual commercial information. Journal of Consumer Psychology, 1(1), 83-102.

Debevec, K., H. E. Spotts, and J. B. Kernan. (1987). The self-reference effect on persuasion: implications for marketing strategy. Advances in Consumer Research, 14(1), 417-420.

De Landtsheer, C., P. De Vries, and D. Vertessen. (2008). Political impression management: how metaphors, sound bites, appearance effectiveness, and personality traits can win elections. Journal of Political Marketing, 7(3/4), 217-237.

Dutton, J. E., J. M. Dukerich, and C. V. Harquail. (1994). Organizational images and member identification. Administrative Science Quarterly, 39(2), 239-263.

Epstein, S. (1973). The self-concept revisited: Or a theory of a theory. American Psychologist, 28(5), 404-416.

Feldman, S., and P. J. Conover. (1983). Candidates, issues, and voters: The role of inference in political perception. The Journal of Politics, 45(4), 810-839.

Ferrandi, J. M., and P. Valette-Florence. (2002). Premiers test et validation de la transposition d'une échelle de personnalité humaine aux marques. Recherche et Apllications en Marketing, 17(3), 21-40.

Ferrandi, J. M., P. Valette-Florence, and S. Fine-Falcy. (2000). Aaker's brand personality in a French context: A replication and preliminary test of validity, Developments in Marketing Science, 23, 7-13.

Fiske, S. T., and S. E. Taylor. (1984). Social cognition. New York, NY: Random House.

French, A., and G. Smith. (2010). Measuring political brand equity: A consumer oriented approach. European Journal of Marketing, 44(3/4), 460-477.

Goldberg, L. R. (1990). An alternative "description of personality": the Big-Five factor structure. Journal of Personality and Social Psychology, 59(6), 1216-1229.

Gopoian, J. D. (1993). Images and issues in the 1988 presidential election. Journal of Politics, 55(1), 151-166.

Guzmán, F., and A. K. Paswan. (2009). Cultural brands from emerging markets: Brand image across home and host countries. Journal of International Marketing, 17(3), 71-86.

Guzmán, F., and V. Sierra. (2009). A political candidate's brand image scale: Are political candidates brands? Journal of Brand Management, 17(3), 207-217.

Hair, J. F., W. C. Black, B. J. Babin, and R. E. Anderson. (2010). Multivariate data analysis. Upper Saddle River, NJ: Prentice Hall.

Harris, P., and A. Lock. (2010). "Mind the gap": The rise of political marketing and a perspective on its future agenda. European Journal of Marketing, 44(3/4), 297-307.

Helgeson, J. G., and M. Supphellen. (2004). A conceptual and measurement comparison of self-congruity and brand personality: The impact of socially desirable responding. International Journal of Market Research, 46(2), 205-233.

Henneberg, S. C., and N. J. O'Shaughnessy. (2007). Theory and concept development in political marketing: Issues and an agenda. Journal of Political Marketing, 6(2/3), 5-31.

Hockett, J. (2005). Brand "W" and the marketing of an American president: Or logos as logos. Westminster Papers in Communication and Culture, 2(2), 72-96.

Kapferer, J. N. (2004). The new strategic brand management: Creating and sustaining brand equity long term. London, UK: Kogan Page. 
Kaplan, M. D., O. Yurt, B. Guneri, and K. Kurtulus. (2010). Branding places: Applying brand personality concept to cities. European Journal of Marketing, 44(9/10), 1286-1304.

Keller, K. L. (2003). Strategic brand management: Building measuring, and managing brand equity. Upper Saddle River, NJ: Prentice Hall.

Lacan, J. (2001). The mirror stage as formative of the I. In Ecrits, trans. A. Sheridan. London: Routledge.

Lock, A., and P. Harris. (1996). Political marketing-vive la difference. European Journal of Marketing, 30(10/11), 21-31.

Lott Jr., J. R. (1991). Does additional campaign spending really hurt incumbents? The theoretical importance of past investments in political brand name. Public Choice, 72(1), 87-92.

Marin, L., and S. Ruiz. (2007). "I need you too!" Corporate identity attractiveness for consumers and the role of social responsibility. Journal of Business Ethics, 71(3), 245-260.

Markus, H. (1977). Self-schemata and processing information about the self. Journal of Personality and Social Psychology, 35(2), 63-78.

Miller, A. H., M. P. Wattenberg, and O. Malanchuck. (1996). Schematic assessments of presidential candidates. The American Political Science Review, 80(2), 521-540.

Myers-Levy, J., and L. A. Peracchio. (1996). Moderators of the self-reference on persuasion. Journal of Consumer Behavior, 22(4), 408-423.

Nakanishi, M., L. G. Cooper, and H. H. Kassarjian. (1974). Voting for a political candidate under conditions of minimal information. Journal of Consumer Research, 1(2), 36-43.

Needham, C. (2006). Brands and political loyalty. Journal of Brand Management, 13(3), 178-187.

Newman, B. I. (1994). The marketing of the president: Political marketing as campaign strategy. Thousand Oaks, CA: Sage.

Newman, B. I. (1999). A predictive model of voter behavior: The repositioning of Bill Clinton. In B. I. Newman (Ed.), Handbook of Political Marketing 259-282. Thousand Oaks, CA: Sage.

Newman, B. I., and J. N. Sheth. (1985). A model of primary voter behavior. Journal of Consumer Research, 12(2), 178-187.

Nunnaly, J. C. (1978). Psychometric theory. New York, NY: McGraw-Hill.

O'Cass, A. (1996). Political marketing and the marketing concept. European Journal of Marketing, 30(10/11), 37-53.

Payne, J. W. (1976). Task complexity and contingent processing in decision making. Organizational Behavior and Human Performance, 16(2), 366-387.

Phipps, M., J. Brace-Govan, and C. Jevons. (2010). The duality of political brand equity. European Journal of Marketing, 44(3/4), 496-514.

Plummer, J. T. (1984/85). How personality makes a difference. Journal of Advertising Research, 24(6), 27-31.

Popkin, S., J. W. Gorman, C. Phillips, and J. A. Smith. (1976). Comment: What have you done for me lately? Toward an investment theory of voting. The American Political Science Review, 70(3), 779-805.

Reeves, P., L. de Chernatony, and M. Carrigan. (2006). Building a political brand: Ideology or voter-driven strategy. Journal of Brand Management, 13(6), 418-428. 
Richardson, M. W. (1938). Multidimensional psychophysics, Psychological Bulletin, 35, 659-660.

Ries, A. (2008). What marketers can learn from Obama's campaign: Change-and positioning-you can believe in. Advertising Age. http://adage.com/print? article_id $=132237$

Rogers, T. B., N. A. Kupier, and W. S. Kirker. (1977). Self-reference and the encoding of personal information. Journal of Personality and Social Psychology, 35(9), 677-688.

Rosenberg, S. W., L. Bohan, P. McCafferty, and K. Harris. (1986). The image and the vote: the effect of candidate presentation on voter preference. American Journal of Political Science, 30(1), 108-127.

Rosenberg, S. W., and P. McCafferty. (1987). The image and the vote: Manipulating voters' preferences. Public Opinion Quarterly, 51(1), 31-47.

Schneider, H. (2004). Branding in politics-manifestations, relevance and identity-oriented management. Journal of Political Marketing, 3(3), 41-67.

Scott, S. G., and V. R. Lane. (2000). A stakeholder approach to organizational identity. Academy of Management Review, 25(1), 43-62.

Shama, A. (1976). The marketing of political candidates. Journal of the Academy of Marketing Science, 4(4), 764-777.

Sigelman, C. K., D. B. Thomas, L. Sigelman, and F. D. Ribich. (1986). Gender, physical attractiveness, and electability: An experimental investigation of voter biases. Journal of Applied Social Psychology, 16(3), 229-248.

Smit, E. G., E. van den Berge, and G. Franzen. (2003). Brands are just like real people! The development of SWOCC's brand personality scale. In F. Hansen and L. B. Christensen (Ed.), Branding and Advertising (pp. 22-43). Copenhagen: Copenhagen Business School Press.

Smith, G. (2001). The 2001 general election: factors influencing the brand image of political parties and their leaders. Journal of Marketing Management, 17(9/10), 989-1006.

Smith, G. (2009). Conceptualizing and testing brand personality in British politics. Journal of Political Marketing, 8(3), 209-232.

Smith, G., and A. French. (2009). The political brand: A consumer perspective. Marketing Theory, 9(2), 208-226.

Sujan, M., J. R. Bettman, and H. Baumgartner. (1993). Influencing consumer judgments using autobiographical memories: A self-referencing perspective. Journal of Marketing Research, 30(4), 422-436.

Supphellen, M., and K. Grønhaug. (2003). Building foreign brand personalities in Russia: The moderating effect of consumer ethnocentrism. International Journal of Advertising, 22(2), 203-226.

Torgerson, W. S. (1952). Multidimensional scaling: I. Theory and method. Psychometrika, 17(4), 401-419.

White, J., and L. de Chernatony. (2002). New Labour: A study of the creation, development and demise of a political brand. Journal of Political Marketing, 1(2/3), 42-52.

Young, F. W., and R. M. Hamer. (1994). Theory and applications of multidimensional scaling. Hillsdale, NJ: Erlbaum Associates. 